\title{
The Effect of Implementing Occupational Health and Safety Programs on Suspected COVID-19 Incidents in PT. Maruki International Employees
}

\author{
Abdul Muis ${ }^{1}$, Muhammad Rifai ${ }^{2}$, Rahmawati Azis $^{3}$, Musfirah $^{4}$ \\ ${ }^{1,2,3,4}$ Department of Magister Public Health, Sekolah Tinggi Ilmu Kesehatan Tamalatea, Makassar Indonesia
}

Corresponding Author: Abdul Muis

\begin{abstract}
World Health Organization (WHO) has shown Corona Virus Disease 2019 as a pandemic. The spread of COVID-19 in Indonesia has now spread across locations and across countries, accompanied by an increase in the number of problems and/or the number of deaths. To overcome the spread of Covid-19, both the government and business actors have made various efforts so that the spread of the Covid19 virus can be prevented and overcome, especially the spread of the Covid-19 virus in office areas by implementing new normal rules in the workplace through the Occupational Safety and Health program. Based on the results of observations from one of the lead managers of PT Maruki International Indonesia, who said that there had been cases against some of his employees who were suspected of being suspected of having COVID-19, we as authors consider it necessary to raise this issue to be investigated for input for the company so that it can be used to implement the implementation. Occupational Health and Safety program against suspected cases of the Covid-19 virus among PT Maruki International Indonesia employees. The purpose of this study was to determine the effect of the implementation of the Occupational Health and Safety Program on the incidence of suspected Covid-19 virus among employees of PT Maruki International Indonesia. This type of research is quantitative research with a design approach cross sectional study. The sample used is 150 employees from a population of 241 employees. Collecting quantitative data using a checklist and analyzed by univariate, bivariate. Thus, it can be said that the Behavioral Improving Body Immunity variable affects the
\end{abstract}

variable incidence of suspected covid-19. It is hoped that with the results of this study the government and related company management can provide a policy to deal with the spread of the corona virus in the workplace.

Keywords: Activities of wearing masks; hand washing habits; efforts to maintain distance and suspected cases of covid-19

\section{BACKGROUND}

World Health Organization (WHO) has shown Corona Virus Disease 2019 as a pandemic. The spread of COVID-19 in Indonesia has now spread across locations and across countries, accompanied by an increase in the number of problems and/or the number of deaths. This situation is increasingly having an impact on political, economic, social, cultural, defense and security aspects, and including the welfare of the people in Indonesia, so that comprehensive strategies and efforts are needed in accelerating the handling of COVID-19. Observing the spread and transmission of COVID-19 in Indonesia which is becoming a concern, the Government through Presidential Decree No. 11 of 2020 concerning the Determination of the Corona Virus Disease 2019 Public Health Emergency in Indonesia, namely determining Corona Virus Disease 2019 as a type of disease that causes a public health emergency and determining a health emergency. Corona Virus Disease 2019 community in Indonesia 
which must be carried out in response to business in accordance with the provisions of statutory decisions. ${ }^{[1]}$

Presidential Decree Number 12 of 2020 concerning the Determination of NonNatural Disasters for the Spread of Corona Virus Disease 2019 as a National Disaster, which states that the management of national disasters caused by the spread of Corona Virus Disease 2019 is carried out by the Task Force for the Acceleration of Handling Corona Virus Disease 2019 and the Governors, Regents, and The Mayor as Chair of the Task Force for the Acceleration of Handling Corona Virus Disease 2019 in the regions and in determining policies in their respective areas needs to pay close attention to the policies of the Central Government for the handling of the COVID-19 pandemic, this needs a role and includes coming from all parties, both the Central Government, regional governments, other parties, private sector and all elements of society in the territory of the Unitary State of the Republic of Indonesia. The business world and the working community have a big contribution to make in breaking the chain of transmission due to the large number of working population and large mobility and including community fabrics, mostly due to work activities. The workplace as a locus of communication and gathering of people is an aspect of risk that must be anticipated as a place for transmission.

Government Regulation Number 21 of 2020 concerning Large-Scale Social Restrictions in the Context of Accelerating the Handling of Corona Virus Disease 2019 has proven that Large-Scale Social Restrictions (PSBB) are carried out correctly, namely by closing work areas. However, the world of work is not likely to keep employees or employees off, the wheels of the economy need to always run. For this reason, after the implementation of the PSBB together with the ongoing COVID-19 pandemic conditions, it is necessary to carry out mitigation efforts and workplace readiness as optimally as possible so that they can adapt through changes in lifestyle to COVID-19 (New Normal) conditions. By applying government provisions no. 21 yrs. 2020 is expected to be able to minimize the risks and effects of the COVID-19 pandemic on the workplace, especially offices and industry, where there is a potential for COVID-19 transmission due to the gathering of a number of people in one area.

Since the COVID-19 problem was first discovered in Wuhan in December 2019 it has been recorded in the world today until January 2021 as many as 109 million covid-19 problems, 2.42 million of them died. March 2, 2020. Until February 14, 2021, the COVID-19 problem in Indonesia has reached 1.22 million confirmed cases with 14,518 new problems per day, along with the quantity of mortality due to COVID-19 which is 33,367 cases. Indonesia's recovery rate was recorded at $82.2 \%$, but in other aspects Indonesia's case fatality rate was $2.97 \%$, where the next figure was always above the world's death rate of $2.16 \%{ }^{[2]}$. Through the Ministry of Health, the Indonesian Government, ordered the implementation of COVID-19 prevention efforts as recommended by WHO, namely awareness and compliance in wearing masks when outside the residence and washing hands with soap ${ }^{[3]}$.

The Ministry of Health of the Republic of Indonesia through HK.01.07/MENKES/413/2020 decided guidelines for preventing and controlling COVID-19 in the community, including physical distancing, maintaining hand hygiene, coughing/sneezing etiquette, using masks, limiting activities outside the home, taking into account large-scale social restrictions., ensuring access to hand hygiene in front of facilities in open spaces and public transportation centers by jointly making preparations for hand washing facilities ${ }^{33}$. South Sulawesi is a province with a number of problems that are increasing too rapidly. Data on COVID-19 issues based on the South Sulawesi Covid response team on February 11, 2021, South 
Sulawesi recorded 3,588 active confirmations. ${ }^{[4]}$ Government, employers and workers face major challenges in their efforts to combat the Covid-19 pandemic and protect safety and health in the country. workplace. To overcome the spread of Covid-19, both the government and business actors have made various efforts so that the spread of the Covid-19 virus can be prevented and overcome, especially the spread of the Covid-19 virus in the office area by implementing the New Normal rules in the workplace through the Occupational Health and Safety program.

The Occupational Safety and Health Program is a program carried out by an organization as an effort to add protection for workers and other people who are in the workplace or company in a safe and healthy situation and so that each source of production is used effectively and efficiently ${ }^{[5]}$. Occupational safety and health is one of the key aspects in business continuity and worker assistance. The Covid-19 pandemic is a momentum for business people and all business actors regarding the importance of implementing occupational safety and health, especially in the field of occupational health in an efficient and efficient manner in all work areas. Business actors are encouraged to apply occupational safety and health protocols in their respective work environments or areas, in order to remain productive so that economic activities can run safely and healthily. The occupational safety and health program is an important aspect in maintaining business continuity and protecting workers or laborers in the context of preventing and overcoming Covid-19 in the work environment. However, if the requirements for work safety and freshness are carried out in accordance with the provisions of laws and regulations and apply a culture of safety and work freshness as well as implement prevention standards and protocols, the work area will avoid the spread of Covid19.
Fahrul Azwar (2020) said that the implementation of the occupational safety and health program could support the implementation of the "new normal" in office premises. The implementation of occupational safety and health can refer to SNI ISO45001:2018. Handling occupational safety and health is one of the protections of the workforce which aims to maintain and improve the health of the workforce in order to achieve optimal health degrees, both physically and mentally to achieve the best possible work efficiency and productivity [6].

This is done so that companies can protect their workers from the spread of this virus so that company activities can continue to run.

In line with the results of research (Ferial, 2020) showing that as a result of the Covid-19 virus pandemic, all companies are required to be able to learn and know about the implementation of health protocols and also carry out occupational safety and health so that companies can survive and can issue several policies that are beneficial to efforts to prevent the spread of the Corona virus in the workplace. ${ }^{[7]}$

Likewise, the research results of $\mathrm{M}$. Rizqi Agustino et al (2020) show that as a result of the Covid-19 virus pandemic, all company HRD are required to be able to learn and be aware of the freshness protocol and implement work safety and freshness. [8].

In research conducted by Supanto \& Gaos, it shows that the Covid-19 pandemic has made changes in daily life and also in the company environment. Discipline is very important as the main key in preventing the transmission of Covid-19. Companies must comply with health protocols, namely wearing masks, washing hands or using hand sanitizer, protecting the distance between workers. The Covid-19 pandemic has changed new behavior towards employees, namely much more attention to cleanliness, fitness and safety in the company environment. 
Minister of Health of the Republic of Indonesia dr. Terawan Agus Putranto said:

"The business world and the working community have a major contribution to make in breaking the chain of transmission due to the large number of working population and high mobility, and population interaction is generally caused by work activities". ${ }^{[9]}$.

The workplace is a special location for interaction and gathering of people who have a risk aspect that must be anticipated for transmission. The Ministry of Health has set guidelines for preventing and controlling the Covid-19 virus in office and industrial places to support business continuity in dealing with the current pandemic situation, namely through the Decree of the Minister of Health Number HK.01.07/MENKES/ $328 / 2020$. This guide contains things that must be carried out by companies in preventing and handling the spread of Covid-19 as well as regulating coordination between companies or office premises and local governments in handling Covid-19.

The Ministry of Manpower seeks to encourage work areas in carrying out disease prevention efforts in the workplace, as an absolutely essential aspect of assistance for workers to ensure occupational safety and health. The following efforts are intended to create a safe, healthy and prosperous work environment in order to achieve optimal work productivity. All parties as well as each work area must anticipate in a real and precise manner and also increase vigilance against the pandemic of the disease. Thus, it is deemed obligatory to take strategic, systematic and effective steps as prevention and control measures against COVID-19 together with the application of occupational health and safety protocols to prevent transmission of COVID-19 in the workplace $^{[2]}$.

One of the companies in Makassar, namely PT Maruki International Indonesia, is a national-scale company that has also felt the influence of the Covid-19 pandemic. To ensure the safety and health of employees from the spread of the Covid-19 virus. PT Maruki International Indonesia has established The New Normal Working Condition Guidelines as a form of Occupational Health and Safety program in the Work Environment. This work guide has been prepared by PT Maruki International Indonesia. According to Law No. 1 of 1970 the implementation of occupational health is a company obligation that must be implemented. Article 3 of Law no. 1 of 1970 concerning Occupational Safety, it is explained that the objectives of implementing occupational health include: 1) Preventing and controlling the incidence of occupational diseases, either physical or physical, transmission, infection and poisoning; 2) Obtain sufficient and appropriate information; 3) Organizing adequate air refreshment; 4) Maintain cleanliness, health and order.

According to Leon C. Meggison in Ferial, (2020:271) occupational health refers to conditions that are safe from physical, mental, emotional or pain disorders and losses caused by the work environment. Companies must provide protection for workers during their work from possible hazards that can endanger the health and safety of workers. The aim is for every employee to get a guarantee of occupational safety and health both physically, socially and psychologically as well as to maintain employee productivity ${ }^{[7]}$.

Based on the results of observations from one of the lead managers of PT Maruki International Indonesia, who said that there had been cases of several of his employees suspected of being suspected of being COVID-19, we as authors consider it necessary to raise this issue to be investigated for input for the company so that it can be used to implement the program implementation. Occupational Safety and Health regarding the suspected case of the Covid-19 virus among PT Maruki International Indonesia employees. The aim is to find out how the impact of implementing the implementation of the occupational safety and health program 
carried out by PT Maruki International Indonesia in an effort to maintain the occupational safety and health of all its employees from the spread of the Covid-19 virus so as not to interfere with office activities and also disrupt the work productivity of employees and other parties. relating to PT Maruki International Indonesia.

\section{METHOD}

Type of research used is quantitative research with a design approach crosssectional study which is an observational (non-experimental) which is only descriptive and also an analytic study. Cross sectional includes all types of research where the measurement of the variables is only done once, at a time, the sample in this study is 150 people.

\section{RESULTS}

Table 1. Distribution of Frequency and Percentage of Respondents

\begin{tabular}{|l|l|l|}
\hline Characteristics & n & $\%$ \\
\hline Age (Years) & & \\
\hline $20-24$ & 1 & 0.7 \\
\hline $25-29$ & 17 & 11.3 \\
\hline $30-34$ & 24 & 16.0 \\
\hline $35-39$ & 20 & 13.3 \\
\hline $40-44$ & 51 & 34.0 \\
\hline $45-49$ & 20 & 13.3 \\
\hline $50-54$ & 17 & 11.3 \\
\hline Gender & & \\
\hline Male & 102 & 68.0 \\
\hline Female & 48 & 32.0 \\
\hline Length of Service (Years) & & \\
\hline $6-10$ & 50 & 33.3 \\
\hline $11-15$ & 21 & 14.0 \\
\hline $16-20$ & 39 & 26.0 \\
\hline $21-24$ & 40 & 26.7 \\
\hline Education & & \\
\hline junior high school & 5 & 3.3 \\
\hline public high schools & 134 & 89.3 \\
\hline Degree / Diploma & 11 & 7.3 \\
\hline
\end{tabular}

Based on the characteristics of the distribution of age, found respondents with age range group 20-24 years old has a percentage of $1(0.7 \%)$ people, the 25-29 year age group has a percentage of 17 (11.3\%) people, the $30-34$ year old group has a percentage of $24(16.0 \%)$ people, the 35-39 year age group has a percentage of 20 (13.3\%) people, the 40-44 year age group has a percentage of $51(34.0 \%)$ people, the 45-49 year age group has a percentage amounted to $20(13.3 \%)$ people, the age group 50-54 years had percentage of 17 (11.3\%) people.

Based on the distribution of gender characteristics, it was found that male respondents had a percentage of 102 (68.0\%) people while female respondents were $48(32.0 \%)$.

Based on the distribution of the characteristics of the length of work, it was found that respondents with a length of work between 6-10 years had a percentage of $50(33.3 \%)$ people, respondents with a length of work between 11-15 years had a percentage of $21(14.0 \%)$ people, respondents The percentage of people who worked between 16-20 years had a percentage of 39 (26.0\%) people, respondents with a length of work between 20-24 years had a percentage of 40 (26.7\%) people.

Based on the distribution of educational characteristics, it was found that respondents who had a junior high school education level had a percentage of $5(3.3 \%)$ people, respondents who had a high school education level had a percentage of 134 (89.3\%) people while respondents who had the level of undergraduate or diploma education has a percentage of 11 (7.3\%) people.

Table 2. The Relationship of Wearing Masks with Suspected Events of Covid-19

\begin{tabular}{|c|c|c|c|c|c|}
\hline \multirow[t]{2}{*}{ Variable } & & \multicolumn{2}{|c|}{ Covid-19Incident } & \multirow[t]{2}{*}{ Total } & \multirow{2}{*}{$\begin{array}{l}p- \\
\text { value }\end{array}$} \\
\hline & & Suspected & $\begin{array}{l}\text { Not } \\
\text { suspected }\end{array}$ & & \\
\hline \multicolumn{5}{|c|}{ Activity Wearing a mask } & 0.000 \\
\hline \multirow[t]{2}{*}{ Yes } & $\mathrm{n}$ & 22 & 89 & 111 & \\
\hline & $\%$ & 14.6 & 59.4 & 74.0 & \\
\hline \multirow[t]{2}{*}{ No } & $\mathrm{n}$ & 27 & 12 & 39 & \\
\hline & $\%$ & 18.0 & 8.0 & 26.0 & \\
\hline \multicolumn{5}{|c|}{ Hand washing habit } & 0.485 \\
\hline \multirow[t]{2}{*}{ Get used to } & $\mathrm{n}$ & 49 & 100 & 149 & \\
\hline & $\%$ & 32.6 & 66.7 & 99.3 & \\
\hline \multirow[t]{2}{*}{ Not used } & $\mathrm{n}$ & 0 & 1 & & \\
\hline & $\%$ & 0.0 & 0.7 & 0.7 & \\
\hline \multicolumn{5}{|c|}{ Efforts to Maintain Distance (Physical distancing) } & 0,000 \\
\hline \multirow[t]{2}{*}{ Applying } & $\mathrm{n}$ & 20 & 86 & 106 & \\
\hline & $\%$ & 13.3 & 57.4 & 70.7 & \\
\hline \multirow{2}{*}{$\begin{array}{l}\text { Not } \\
\text { applying }\end{array}$} & $\mathrm{n}$ & 29 & 15 & 44 & \\
\hline & $\%$ & 19.3 & 10.0 & 29.3 & \\
\hline \multicolumn{5}{|c|}{ Behavior to increase immunity } & 0.000 \\
\hline \multirow[t]{2}{*}{ Doing } & $\mathrm{n}$ & 24 & 93 & 117 & \\
\hline & $\%$ & 16.0 & 62.0 & 78.0 & \\
\hline \multirow[t]{2}{*}{ Not doing } & $\mathrm{n}$ & 25 & 8 & 33 & \\
\hline & $\%$ & 16.7 & 5.3 & 22.0 & \\
\hline
\end{tabular}


Based on Table 2 it is known that the respondents who are categorized as wearing masks who are suspected of having Covid19 are $22(14.6 \%)$ people, while respondents who were not suspected of being suspected of having COVID-19 were 89 (59.4\%) and respondents who were categorized as not wearing masks who were suspected of being suspected of being COVID-19 were 27 (18.0\%) while respondents who were not suspected of being suspected of being COVID-19 were as many as $12(8.0 \%)$ people.

The results of the statistical test obtained a p-value of $0.000<0.05$, so it can be concluded that there is a significant relationship between the activity variable wearing masks and the incidence of suspected COVID-19.

Based on Table 2, it is known that the respondents who are categorized as having a habit of washing hands who are suspected of being suspected of Covid-19 are $49(32.6 \%)$ while respondents who are not suspected of being suspected of being Covid-19 are 100 (66.7\%) and respondents who are categorized as It is not a habit to wash hands with $0(0 \%)$ people suspected of being suspected of being Covid-19, while 1 $(0.7 \%)$ of respondents who are not suspected of being suspected of having COVID-19 are.

The results of the statistical test obtained a p-value of $0.485>0.05$, it can be concluded that there is no significant relationship between the variables of hand washing habits and the incidence of suspected covid-19.

Based on Table 2, it is known that the respondents who are categorized as implementing social distancing who are suspected of being suspected of Covid-19 are $20(13.3 \%)$ while respondents who are not suspected of being suspected of being COVID-19 are 86 (57.4\%) and respondents who are categorized as No. Implementing Efforts to Maintain Distance with 29 (19.3\%) suspected COVID-19 suspects while $15(10.0 \%)$ respondents were not suspected of having COVID-19 suspects.
The results of the statistical test obtained a p-value of $0.000<0.05$, so it can be concluded that there is a significant relationship between the variable Efforts to Maintain Distance (Physical Distancing) to the incidence of suspected covid-19.

Based on 2, it is known that the respondents who are categorized as carrying out activities with suspected Covid-19 suspects are $24(16.0 \%)$ people while respondents who are not suspected of having Covid-19 are 93 (62.0\%) people and respondents who are categorized as not doing activities. There were $25(16.7 \%)$ people suspected of being suspected of having COVID-19, while $8(5.3 \%)$ of respondents who were not being suspected of being suspected of being Covid-19 were $8(5.3 \%)$.

The results of the statistical test obtained a $p$-value of $0.000<0.05$, so it can be concluded that there is a significant relationship between the Behavioral Improving Body Immunity variable on the incidence of suspected covid-19.

\section{DISCUSSION}

Based on the results of research obtained at PT Maruki International Indonesia, from 150 respondents and the results of the chi-square statistical test and binary logistic regression test of the independent variable on the dependent variable, namely the influence of the variables on Activity Wearing Masks, Washing Hands and Efforts to Maintain Distance (Physical Distancing). ) and Behavior to Increase Body Immunity against the variable incidence of suspected covid-1

Although the activity of wearing a mask did not significantly affect the incidence of suspected Covid-19, but according to the results of direct observations made there are still most employees who still carry out the activity of wearing masks in a disciplined manner. This is explained in the journal The Indonesian Journal of Development Planning Volume IV No. 2 - June 2020 that the Government 
provides additional guidelines on how to live a new normal that must be carried out by the community in 7 norms, namely: (1) Washing hands; (2) Avoid touching the face avoid touching the face area; (3) Applying coughing and sneezing etiquette while coughing or sneezing because the body will expel the virus from the body; (4) Wear a mask while appearing home or interacting with other people; (5) Maintain social distance to avoid exposure to the virus; (6) Self-isolation. This is done for those who feel unwell, such as having more than one symptom of illness, namely fever, cough, runny nose, sore throat or shortness of breath; and (7) Maintaining joint health by emphasizing physical health, sunbathing in the morning, consuming nutritious food, and doing easy exercise ${ }^{[9]}$.

The Effect of Handwashing Habits with Suspected Events of Covid-19 As quoted from the results of research conducted by Moh. Rivai Nakoe et al (2020) regarding the difference in the effectiveness of hand sanitizers by washing hands with soap as a form of prevention of covid-19, it was found that the things that need to be remembered when washing hands: 1) If it is clearly visible or contaminated by materials containing protein, hands must be washed with detergent and running water. 2) If hands are not clearly visibly dirty or contaminated, an alcohol-based hand rub should be used for routine hand decontamination. 3) Before starting the activity, make sure the hands are dry ${ }^{[10]}$.

Indications for hand washing: 1) Do it immediately after arriving at work. 2) Do it before: a) Make direct contact with sufferers; b) Performing clinical examinations and invasive measures (intravascular injections) must use personal protective equipment such as gloves; c) Preparing food; d) Feeding the patient; e) Leave the hospital. 3) Perform certain procedures on the same patient on contaminated hands to avoid crosscontamination. 4) Do it after: a) Make contact with the patient; b) Remove personal protective equipment; c) Remove gloves; d) contact with body fluids, blood, excretions, secretions, wound exudates, and tools suspected of being exposed to body fluids, blood, excretions when wearing gloves or not; e) Using public toilets, and before touching the nose. Therefore, it is recommended to wash hands using soap by washing the fingers with running water so that they become clean and prevent the spread of germs ${ }^{[10]}$.

The results of the study were based on the effect of distancing physical(psychal distancing) with the suspected occurrence of Covid-19, the results of the statistical test chi-square obtained a p-value of 0.000 $<0.05$, it can be concluded that there is a significant relationship between the variables of Efforts to Maintain Distance (Physical Distancing) on suspected cases of covid-19. However, the results of testing the effect of Efforts to Maintain Distance (Physical Distancing) on the incidence of suspected Covid-19 using logistic regression tests, the results show that the Significant value of the variable Efforts to Maintain Distance (Physical Distancing) is 0.266 > 0.05). Thus it can be said that the Efforts to Maintain Distance (Physical Distancing) variable does not significantly affect the variable incidence of suspected Covid-19, but based on the results of direct observations made in the field, it shows that most employees have implemented Efforts to Maintain Distance (Physical Distancing) while working or during breaks. .

This is explained in the theory of research conducted by Karyono, et al, 2020. From the theory it is explained that Social Distancing or Physical Distancing is so far an efficient step in preventing the spread of viruses or diseases, namely through preventing sick people from making close contact with other people to prevent transmission. However, looking at the current phenomenon, in fact social distancing is still in the form of an appeal which if it is not helped to go viral in social facilities, fewer people will know about it, therefore policies social distancing should be included in government regulations in 
lieu of law regarding efforts to handle the Covid-19 outbreak, which is wrong. The only thing that regulates social distancing is an obligation, if necessary there is confirmation in the form of sanctions according to positive law, so that people are not only aware of the importance of social distancing but also implement the practice. It is deemed necessary to limit individual rights in doing social distancing because the condition is an emergency that threatens public health ${ }^{[11]}$.

The term social distancing was then changed to physical distancing in accordance with the term used by WHO because the use of the term social distancing seemed to stop social interaction in the community temporarily, what was actually desired was only to maintain physical distance. From this, various activities that were initially carried out with close physical distance were later turned into activities that created physical distance, among others, online learning (online method), use of WFH (work from home) mechanism, closing of shopping places (Mall).) and other measures that can prevent the spread of Covid-19.

The results of testing the effect of Behavior Increasing Body Immunity on the incidence of suspected Covid-19 using logistic regression tests, the results show that the Significant value of the Behavioral Immune Enhancement variable is 0.042 $<0.05)$. Thus, it can be said that the Behavioral Improving Body Immunity variable significantly affects the variable incidence of suspected Covid-19 cases. So it can be said that respondents who have Behaviors to Increase Body Immunity have a 7 times greater tendency to avoid symptoms of suspected cases of Covid-19. This is based on the results of direct observations carried out where most employees carry out Behavioral activities to Increase Body Immunity, whether it's exercising three times a week and consuming a lot of nutritious food and consuming supplements such as vitamins and can maintain sleep patterns so that respondents can increase their body's immunity so they can fight back. symptoms of suspected corona virus from inside the body.

\section{CONCLUSION}

From the results of the statistical test chi-square, obtained p-value of $0.000<0.05$ was, it can be concluded that there is a significant relationship between the activity variable wearing masks and the incidence of suspected COVID-19. Based on the habit of washing hands, obtained $p$-value of 0.485 > 0.05 was, it can be concluded that there is no significant relationship between the variable of hand washing habits on the incidence of suspected Covid-19, based on the variable of maintaining distance, obtained. $p$-value of $0.000<0$ is 0.05 , it can be concluded that there is a significant relationship between the variable Efforts to Maintain Distance (Physical Distancing) to the incidence of suspected covid-19. Based on the variable of increasing the body's immunity, the obtained p-value of 0.000 $<0.05$ was, it can be concluded that there is a significant relationship between the Behavioral Improving Body Immunity variable and the incidence of suspected COVID-19.

\section{Acknowledgement: None}

Conflict of Interest: None

\section{Source of Funding: None}

\section{Ethical Approval: Approved}

\section{REFERENCES}

1. World Health Organization, W. (2020). Anjuran mengenai penggunaan masker dalam konteks COVID-19. World Health Organization, April, 1-17. https://www.who.int/docs/defaultsource/searo/indonesia/covid19/anjuranmengenai-penggunaan-masker-dalamkonteks-covid-19-june20.pdf?sfvrsn=d1327a85_2

2. International Labour Organization,Kemnaker, P. D. K. K. I. 
Abdul Muis et.al. The effect of implementing occupational health and safety programs on suspected Covid-19 incidents in PT. Maruki international employees.

(n.d.). Pencegahan dan Penanggulangan COVID-19 Pencegahan dan Penanggulangan COVID-19 di Tempat Kerja.

3. Kementerian kesehatan Republik Indonesia. (2020). Pencegahan Covid-19 di Tempat Kerja Era New Normal. Kementerian Kesehatan Republik Indonesia, 19, 2-5.

4. Covid -19, T. S.-S. tanggap. (2021). Data Pantauan Covid - 19 di Sulawesi Selatan. 11 Februari 2021.

5. Keputusan Menteri Kesehatan Republik Indonesia. (2020). Keputusan Menteri Kesehatan Republik Indonesia Nomor HK.01.07/MenKes/413/2020 Tentang Pedoman Pencegahan dan Pengendalian Corona Virus Disease 2019 (Covid-19). MenKes/413/2020, 2019.

6. Anwar Prabu Mangkunegara. (2002). Manajemen Sumber Daya Manusia Perusahaan.

7. Ferial, R. M. (2020). Penerapan Keselamatan Dan Kesehatan Kerja (K3) Dalam Upaya Pencegahan Penyebaran Virus Covid-19 Pada Area Kerja Pt. Semen Padang. JESS (Journal of Education on Social Science), 4(2), 271-284. http://jess.ppj.unp.ac.id/index.php/JESS/arti cle/view/287

8. Perdana, R. C., Agustino, M. R., Hartawan, D., SUYOSO, Y. A., \& SARI, R. (2020). Adaptasi dan Kebiasaan Baru Human Resource Department di Masa Pandemik Covid-19. Business Innovation and Entrepreneurship Journal, 2(3), 201-204. https://doi.org/10.35899/biej.v2i3.138

9. Putranto, T. A. (2020). Keputusan Menteri Kesehatan Republik Indonesia Nomor Hk.01.07/Menkes/328/2020 Tentang
Panduan Pencegahan Dan Pengendalian Corona Virus Disease 2019 (Covid-19) Di Tempat Kerja. Menteri PUTRANTO, T. A. (2020). Keputusan Menteri Kesehatan Republik Indonesia Nomor Hk.01.07/Menkes/328/2020 Tentang Panduan Pencegahan Dan Pengendalian Corona Virus Disease 2019 (Covid-19) Di Tempat Kerja. Menteri Kesehatan Republik Indonesia, 2019, 1-2, 2019, 1-207.

10. Muhyiddin. (2020). Covid-19, New Normal, dan Perencanaan Pembangunan di Indonesia. Jurnal Perencanaan Pembangunan: The Indonesian Journal of Development Planning, 4(2), 240-252. https://doi.org/10.36574/jpp.v4i2.118

11. Nakoe, R., S Lalu, N. A., \& Mohamad, Y. A. (2020). Perbedaan Efektivitas HandSanitizer Dengan Cuci Tangan Menggunakan Sabun Sebagai Bentuk Pencegahan Covid-19. Jambura Journal of Health Sciences and Research, 2(2), 65-70. https://doi.org/10.35971/jjhsr.v2i2.6563

12. Karyono, K., Rohadin, R., \& Indriyani, D. (2020). Penanganan Dan Pencegahan Pandemi Wabah Virus Corona (Covid-19) Kabupaten Indramayu. Jurnal Kolaborasi Resolusi Konflik, 2(2), 164. https://doi.org/10.24198/jkrk.v2i2.29127

How to cite this article: Muis A, Rifai M, Azis $\mathrm{R}$ et.al. The effect of implementing occupational health and safety programs on suspected Covid19 incidents in PT. Maruki international employees. International Journal of Science \& Healthcare Research. 2021; 6(3): 158-166. DOI: https://doi.org/10.52403/ijshr.20210726 